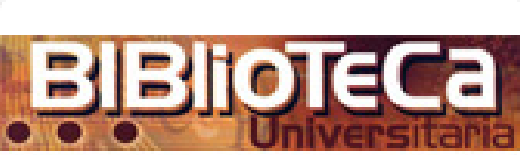

Biblioteca Universitaria

ISSN: 0187-750X

public@dgb.unam.mx

Universidad Nacional Autónoma de México

México

Rodríguez Gallardo, Adolfo

El código de ética para bibliotecarios y otros trabajadores de la información

Biblioteca Universitaria, vol. 15, núm. 2, julio-diciembre, 2012, pp. 169-174

Universidad Nacional Autónoma de México

Distrito Federal, México

Disponible en: http://www.redalyc.org/articulo.oa?id=28528265006

- Cómo citar el artículo

- Número completo

- Más información del artículo

Página de la revista en redalyc.org



Sistema de Información Científica

Red de Revistas Científicas de América Latina, el Caribe, España y Portugal

Proyecto académico sin fines de lucro, desarrollado bajo la iniciativa de acceso abierto 


\section{El código de ética para bibliotecarios y otros trabajadores de la información*}

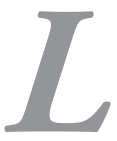

a Federación Internacional de Asociaciones e Instituciones Bibliotecarias (IFLA) acaba de publicar una nueva versión del código de ética que rige a los bibliotecarios y el trabajo que realizan. Podemos decir que toda profesión que presta un servicio directo a los individuos y a la sociedad cuenta con un instrumento como este que guía su conducta profesional. Tal es el caso del famoso juramento de Hipócrates, que no es otra cosa que un código de ética que intenta regular y dirigir sobre principios valorativos la conducta de los médicos.

El caso de los médicos no es el único, pero posiblemente sí es el más famoso. La misma IFLA ha compilado una gran cantidad de códigos de ética, los que pueden ser consultados en la página electrónica de la IFLA http://www.ifla.org Éstos intentan -por una parte- establecer cuáles son los valores que debe sostener, promover, impulsar y respetar la profesión bibliotecaria.

El documento elaborado por la IFLA tiene como meta servir de guía a las asociaciones de bibliotecarios y de trabajadores de la información cuando revisen su código de ética o bien se intente elaborar uno nuevo. De hecho, no es un código en sí mismo sino un documento que sirve de modelo, lo que produce que muchos de sus proposiciones sean generalidades que difícilmente pueden ser objetadas y -por lo tanto- pierden fuerza al plantear algunos de los valores que deben postular los bibliotecarios como valores que deben regir la práctica bibliotecaria. Faltaría incluir algunos principios para los bibliotecarios como docentes o bien como investigadores; el proyecto comentado se limita a las actividades que están dirigidas a la prestación de servicios.

Según se dice en su presentación, el documento intenta servir de apoyo para que las asociaciones elaboren su propio código de ética y para ello se dice que es necesario hacerlo mediante un proceso de investigación, consulta y cooperación.

Se parte del principio de que una base importante sobre la que debe ser construido el código de ética es lo establecido por el artículo 19 de la Declaración de los Derechos del Hombre, publicada por la Organización de las Naciones Unidas en 1948. En este documento se establecen los derechos de opinión, expresión y acceso a la información, lo que posteriormente ha sido denominado el libre acceso al flujo de la información: "El derecho a buscar, recibir y divulgar información e ideas por cualquier medio y sin importar fronteras".

Es necesario, nos dice el documento de la IFLA, partir del reconocimiento de los individuos y la sociedad en relación con la información para emprender cualquier código de ética. Pensar que los bibliotecarios puedan desconocer el derecho de los sujetos a los cuales deben de servir es un contrasentido y es por ello que tales derechos deben ser la base del código de ética que rige los valores de nuestra profesión.

International Federation of Library Associations and Institutions. 
El trabajo tiene dos presentaciones, una corta que se presenta en una página y otra larga que tiene tres páginas, ambas son fundamentalmente iguales, pero la versión corta tiene la ventaja de que al inicio de cada postulado no se repite una frase que parece un mantra y que fundamentalmente dice "los bibliotecarios y otros trabajadores de la información ...", que a fuerza de tanto repetirse llega a ser molesta.

El trabajo está dividido en seis grandes temas:

1. Acceso a la información. En este apartado se establece el compromiso de los bibliotecarios por facilitar el acceso a la información para los fines que el usuario desee, por lo que los bibliotecarios deben rechazar la censura y apoyar las medidas que permitan el acceso sin costo para los usuarios y para ello garantizar los más altos niveles de calidad en el acceso.

2. Responsabilidad hacia los individuos y la sociedad. Los bibliotecarios deben garantizar el libre acceso a todas las personas sin importar su edad, nacionalidad, posición política, capacidades físicas y mentales, educación, ingreso económico, situación migratoria, estado civil, origen, lengua, religión y orientación sexual.

3. Privacidad, secrecía y transparencia. Los bibliotecarios deben proteger la privacidad de la información y los datos personales necesarios para poder interactuar entre los individuos y las instituciones. Los bibliotecarios deben garantizar que las operaciones de la biblioteca estén abiertas al escrutinio general de las instituciones públicas.

4. Acceso abierto y propiedad intelectual. Los bibliotecarios deben proveer a los usuarios el mayor y mejor acceso en cualquier formato. Asimismo, deben garantizar que los derechos de los usuarios y de los creadores sean compatibles y respetados. Deben ser promotores del acceso abierto (open access), fuentes abiertas (open source) y licencias abiertas (open licences).

5. Neutralidad, integridad personal y habilidades profesionales. Los bibliotecarios deben ser imparciales en cuanto al desarrollo de colecciones, acceso y servicio.

6. Colegas y empleadores. Los bibliotecarios tratan con respeto a sus colegas y se oponen a todo tipo de discriminación basada en la edad, ciudadanía, pensamiento político, habilidad mental, género, estado civil, origen, raza, religión u orientación sexual. Promueven el pago igual a trabajo igual sin importar el género. Comparten su conocimiento y experiencia y contribuyen al trabajo de las asociaciones profesionales.

Como se puede ver, el listado de principios y valores es muy amplio y diverso. Se incluyen desde los que son valores esenciales para la profesión y sus relación con el usuario, hasta otros que son valores generales que deben ser apoyados para que exista una sociedad más armónica y colaborativa. Algunas propuestas tienen que ver con el servicio pero de forma lejana, tal es el caso de la colaboración con las asociaciones profesionales.

El listado es muy largo y complejo. En algunas asociaciones -como es el caso de la American Library Association- el código de ética es más conciso y se imprime en el reverso de la credencial que acredita a un bibliotecario como afiliado a la ALA.

Dentro de los principios de la IFLA se incluyen algunos que tienen que ver con valores sociales que hace algunos pocos años no se considerarían como principios éticos de la profesión, como por ejemplo aquellos relacionados con las diferencias sexuales, entre otros.

\section{Adolfo Rodríguez Gallardo*}

Se incluye el código de ética publicado por la IFLA en su versión original en inglés.

** Director general de Bibliotecas de la Universidad Nacional Autónoma de México (UnAm) e investigador emérito en el Instituto de Investigaciones Bibliotecológicas y de la Información de esta misma casa de estudios. Entrepiso del edificio de Biblioteca Central, Circuito Interior, unAM-Cu, C.P. 04510, México D.F., México. Correo electrónico: jadolfo@unam.mx 


\section{IFLA Code of Ethics for Librarians and other Information Workers}

(full version, August 12th, 2012)

\section{Preamble}

This Code of Ethics and Professional Conduct is offered as a series of ethical propositions for the guidance of individual librarians as well as other information workers, and for the consideration of Library and Information Associations when creating or revising their own codes.

The function of codes of ethics can be described as

- encouraging reflection on principles on which librarians and other information workers can form policies and handle dilemmas

- improving professional self-awareness

- providing transparency to users and society in general.

This code is not intended to replace existing codes or to remove the obligation on professional associations to develop their own codes through a process of research, consultation and cooperative drafting. Full compliance with this code is not expected.

This code is offered in the belief that:

Librarianship is, in its very essence, an ethical activity embodying a value-rich approach to professional work with information. The need to share ideas and information has grown more important with the increasing complexity of society in recent centuries and this provides a rationale for libraries and the practice of librarianship.

The role of information institutions and professionals, including libraries and librarians, in modern society is to support the optimisation of the recording and representation of information and to provide access to it. Information service in the interest of social, cultural and economic well-being is at the heart of librarianship and therefore librarians have social responsibility.

Furthermore, this belief in the human necessity of sharing information and ideas implies the recognition of information rights. The idea of human rights, particularly as expressed in the United Nations Universal Declaration of Human Rights (1948), requires us all to recognise and acknowledge the humanity of others and to respect their rights. In particular, Article 19 sets out rights of freedom of opinion, expression and access to information for all human beings.

Article 19 expressly sets out a right to "Seek, receive and impart information and ideas in any media and regardless of frontiers" which provides a clear rationale for libraries and the practice of modern and progressive librarianship. IFLA in statements, manifestos and policy and technical documents too numerous to list has expanded the understanding of work with information. Implicit in this work is the idea of information rights and their significance for the profession and society generally. The emphasis on information rights in turn obliges librarians and other information workers to develop a principled critique of relevant law and to be prepared to advise and, if appropriate, advocate the improvement of both the substance and administration of laws.

The clauses of this code of ethics build on the core principles outlined in this preamble to provide a set of suggestions on the conduct of professionals. IFLA recognises that whilst these core principles should remain at the heart of any such code, the specifics of codes will necessarily vary according to the particular society, community of practice or virtual community. Code making is an essential function of a professional association, just as ethical reflection is a necessity for all professionals. IFLA recommends the Code of Ethics for IFLA to all its member associations and institutions and to individual librarians and information workers for these purposes.IFLA undertakes to revise this code whenever appropriate.

\section{Access to information}

The core mission of librarians and other information workers is to ensure access to information for all for personal development, education, cultural enrichment, leisure, economic activity and informed participation in and enhancement of democracy. 
Librarians and other information workers reject the denial and restriction of access to information and ideas most particularly through censorship whether by states, governments, or religious or civil society institutions.

Librarians and other information workers offering services to the public should make every endeavour to offer access to their collections and services free of cost to the user. If membership fees and administrative charges are inevitable, they should be kept as low as possible, and practical solutions found so that socially disadvantaged people are not excluded.

Librarians and other information workers promote and publicise their collection and services so that users and prospective users are aware of their existence and availability.

Librarians and other information workers use the most effective ways to make the material accessible to all. For this purpose they seek to ensure that the websites of libraries and other information institutions comply with international standards for accessibility and access to them is not subject to barriers.

\section{Responsibilities towards individuals and society} In order to promote inclusion and eradicate discrimination, librarians and other information workers ensure that the right of accessing information is not denied and that equitable services are provided for everyone whatever their age, citizenship, political belief, physical or mental ability, gender identity, heritage, education, income, immigration and asylum-seeking status, marital status, origin, race, religion or sexual orientation.

Librarians and other information workers respect language minorities of a country and their right to access information in their own language.

Librarians and other information workers organize and present content in a way that allows an autonomous user to find the information s/he needs. Librarians and other information workers help and support users in their information searching.
Librarians and other information workers offer services to increase reading skills. They promote information literacy including the ability to identify, locate, evaluate, organize and create, use and communicate information. And they promote the ethical use of information thereby helping to eliminate plagiarism and other forms of misuse of information.

Librarians and other information workers respect the protection of minors while ensuring this does not impact on the information rights of adults.

\section{Privacy, secrecy and transparency}

Librarians and other information workers respect personal privacy, and the protection of personal data, necessarily shared between individuals and institutions.

The relationship between the library and the user is one of confidentiality and librarians and other information workers will take appropriate measures to ensure that user data is not shared beyond the original transaction.

Librarians and other information workers support and participate in transparency so that the workings of government, administration and business are opened to the scrutiny of the general public. They also recognise that it is in the public interest that misconduct, corruption and crime be exposed by what constitute breaches of confidentiality by so-called 'whistleblowers'.

\section{Open access and intellectual property}

Librarians and other information workers' interest is to provide the best possible access for library users to information and ideas in any media or format. This includes support for the principles of open access, open source, and open licenses.

Librarians and other information workers aim to provide fair, swift, economical and effective access to information for users.

Librarians and other information workers have a professional duty to advocate for exceptions and limitations to copyright restrictions for libraries. 
Librarians and other information workers are partners of authors, publishers and other creators of copyright protected works. Librarians and other information workers recognise the intellectual property right of authors and other creators and will seek to ensure that their rights are respected.

Librarians and other information workers negotiate the most favourable terms for access to works on behalf of their users and seek to ensure that access is not unnecessarily prevented or hindered by the mode of administration of intellectual property laws and that licenses do not override exceptions for libraries contained in national legislation. Librarians and other information workers encourage governments to establish an intellectual property regime that appropriately respects balance between the interests of rightsholders and individuals and the institutions such as libraries which serve them.

Librarians and other information workers also advocate that copyright terms should be limited and that information that has fallen in the public domain remains public and free.

\section{Neutrality, personal integrity and professional skills} Librarians and other information workers are strictly committed to neutrality and an unbiased stance regarding collection, access and service. Neutrality results in the most balanced collection and the most balanced access to information achievable.

Librarians and other information workers define and publish their policies for selection, organisation, preservation, provision, and dissemination of information.

Librarians and other information workers distinguish between their personal convictions and professional duties. They do not advance private interests or personal beliefs at the expense of neutrality.

Librarians and other information workers have the right to free speech in the workplace provided it does not infringe the principle of neutrality towards users.
Librarians and other information workers counter corruption directly affecting librarianship, as in the sourcing and supply of library materials, appointments to library posts and administration of library contracts and finances.

Librarians and other information workers strive for excellence in the profession by maintaining and enhancing their knowledge and skills. They aim at the highest standards of service quality and thus promote the positive reputation of the profession.

\section{Colleague and employer/employee relationship}

Librarians and other information workers treat each other with fairness and respect.

Librarians and other information workers oppose discrimination in any aspect of employment because of age, citizenship, political belief, physical or mental ability, gender, marital status, origin, race, religion or sexual orientation.

Librarians and other information workers promote equal payment and benefits for men and women holding comparable jobs.

Librarians and other information workers share their professional experience with colleagues and they help and guide new professionals to enter the professional community and develop their skills. They contribute to the activities of their professional association and participate in research and publication on professional matters.

Librarians and other information workers strive to earn a reputation and status based on their professionalism and ethical behaviour. They do not compete with colleagues by the use of unfair methods. os 


\section{Further study}

- The Ethics of Librarianship. An International Survey. Ed. By Robert W. Vaagan with an introduction by Alex Byrne. München: Saur, 2002. VI, 344 p.

- Gebolys, Zdzislaw, Jacek Tomaszczyk. Library Codes of Ethics Worldwide. Anthology. Berlin: Simon, 2012. 267 p.

- Professional Codes of Ethics for Librarians. ifla-Committee on Freedom of Access to Information and Free Expression (FAIFE). <http://www.ifla.org/news/ifla-code-of-ethics-for-librarians-and-otherinformation-workers-full-version> [Consulta: 19 marzo 2012].

- Sturges, Paul. Doing the Right Thing. Professional ethics for information workers in Britain. In: New Library World. 104, 2003, n. 1186, p. 94-102. < http://www.fims.uwo.ca/people/faculty/frohmann/ LIS774/Documents/Sturges\%20on\%20codes.pdf> [Consulta: 19 marzo 2012].

Prepared by Loida Garcia-Febo, Anne Hustad, Hermann Rösch, Paul Sturges and Amelie Vallotton (FAlFE working group)

Endorsed by the IFLA Governing Board, August 2012

FAIFE (Committee on Freedom of Access to Information and Freedom of Expression) 